\title{
Ixodes scapularis tick distribution and infection rates in Ottawa, Ontario, 2017
}

\author{
M Kulkarni ${ }^{1 *}$, R Kryuchkov ${ }^{1}$, A Statculescu ${ }^{1}$, C Thickstun ${ }^{1}$, A Dibernardo², L Lindsay ${ }^{2}$, B Talbot ${ }^{1}$
}

\begin{abstract}
Background: The incidence of Lyme disease has increased in many regions of Canada in recent years, including in Ottawa, Ontario. To date there has been limited active tick surveillance in the region.
\end{abstract}

Objectives: To estimate both the distribution and density of Ixodes scapularis ticks in the city of Ottawa, and the infection rates of ticks with Borrelia burgdorferi (that causes Lyme disease) and other tick-borne pathogens.

Methods: Between June and October 2017, tick surveillance was conducted by drag sampling at 23 sites in Ottawa municipal parks, recreational trails and forests. Blacklegged ticks were tested for B. burgdorferi, Borrelia miyamotoi and Anaplasma phagocytophilum using quantitative polymerase chain reaction protocols.

Results: I. scapularis ticks were found in 16 of the 23 sites (70\%). Recreational trails, conservation areas/forests and the provincial park within the city of Ottawa had significantly higher tick densities than municipal parks $(p<0.01)$. Of the 194 adult and 26 nymphal I. scapularis tested, prevalence of infection was $29.5 \%$ for B. burgdorferi, $0.45 \%$ for B. miyamotoi and $0.91 \%$ for $A$. phagocytophilum.

Conclusion: Almost $30 \%$ of $I$. scapularis ticks tested in suburban and rural areas of the city of Ottawa were infected with B. burgdorferi, known to cause Lyme disease. Other types of infection, known to cause anaplasmosis and tick-borne relapsing fever, were also detected, although were very rare. Conducting active tick surveillance at the local level may help to inform risk assessment and public health actions.
Affiliations

${ }^{1}$ University of Ottawa, School of Epidemiology and Public Health, Ottawa, ON

\author{
${ }^{2}$ National Microbiology \\ Laboratory, Public Health Agency \\ of Canada, Winnipeg, MB
}

${ }^{\star}$ Correspondence: manisha. kulkarni@uottawa.ca

Suggested citation: Kulkarni M, Kryuchkov R, Statculescu A, Thickstun C, Dibernardo A, Lindsay L, Talbot B. Ixodes scapularis tick distribution and infection rates in Ottawa, Ontario, 2017. Can Commun Dis Rep

2018;44(10):237-42. https://doi.org/10.14745/ccdr.v44i10a02

Keywords: Lyme disease, surveillance, Ixodes scapularis, Borrelia burgdorferi, ecology

\section{Introduction}

The blacklegged tick (also known as deer tick, Ixodes scapularis) is a vector for several pathogens that cause zoonotic diseases, including Lyme disease $(1,2)$. The geographic range of this tick species extends from Texas in the southern United States (US) to parts of central and eastern Canada (3-5). Recent northward spread of $I$. scapularis has been observed in association with ongoing climate and environmental changes, posing an increasing risk to public health (6).
Eastern Ontario has been identified as a region of recent and ongoing tick and Lyme disease expansion $(7,8)$, where environmental factors such as temperature, forest type and microhabitat conditions have been associated with tick occurrence (4,8-10). With recent climate change, the city of Ottawa has become climatically suitable for the establishment of $I$. scapularis populations (6). The number of reported cases of human Lyme disease more than doubled in Ottawa in the last year, from 74 in 2016 to 186 in 2017, associated with exposures both inside and outside of Ottawa (11). 
Although ticks are most known for carrying the bacteria that causes Lyme disease, they can also carry other pathogens. For example, ticks can carry Anaplasma phagocytophilum that causes anaplasmosis. The first confirmed human case of anaplasmosis in a health unit near Ottawa was reported recently (12). In addition, ticks can carry Borrelia miyamotoi, causing an infection sometimes called tick-borne relapsing fever $(13,14)$. Detection is important as these diseases are treatable and full recovery can be obtained when identified and treated early.

Given the recent increase in the number of cases of Lyme disease reported in Ottawa and ongoing expansion of tick populations in eastern Ontario, there was an identified need for surveillance of tick populations to assess the public health risk and inform public health action. Two types of tick surveillance can be used in a given area: passive and active. Passive surveillance involves health care providers and/or the public submitting ticks that had been attached to people (15). Passive surveillance is useful for signalling the presence of potential risk in areas where ticks and tick-borne pathogens are newly emerging. Active surveillance involves field sampling of ticks from the environment either by dragging a flannel sheet over a potentially affected area or collecting and examining (and possibly testing) ticks infesting small mammal hosts such as mice (15). To determine whether tick populations are established, all three life stages of the tick should be detected for two consecutive years (15).

The objective of this study was to estimate the distribution, density and infection rates of ticks in the city of Ottawa.

\section{Material and Methods}

\section{Study site}

The city of Ottawa is the nation's capital and is situated in eastern Ontario on the south bank of the Ottawa River. It has a population of almost one million people and covers a large geographic area of almost $3,000 \mathrm{~km}^{2}(16)$. In addition to the urban core and several suburban districts, the city has abundant green space including conservation areas, parks, trails, wetlands, forests and farmland.

We conducted a survey of 23 sites including nine municipal parks, seven conservation areas and forests, six recreational trails and one provincial park within the city of Ottawa to assess the occurrence and density of I. scapularis ticks and rates of infection with tick-borne pathogens (Table 1). Sites were selected based on an ecological niche model of $I$. scapularis (10), with locations chosen across urban, suburban and rural areas of Ottawa.

\section{Sample collection}

A team of three researchers with previous field training conducted active tick surveillance using the drag sampling method described by Public Health Ontario (17) at 23 sites: 19 in spring/summer 2017 (June to August) and all 23 sites in fall 2017 (September to October). Ticks were collected by dragging
Table 1: Active tick surveillance sampling sites, Ottawa, Ontario, 2017

\begin{tabular}{|c|c|c|}
\hline $\begin{array}{l}\text { Site } \\
\text { ID }\end{array}$ & Site name & Site type \\
\hline 1 & Britannia Conservation Area & Conservation area and forest \\
\hline 2 & Rideau River Provincial Park & Provincial park \\
\hline 3 & Rideau River Eastern Pathway & Recreational trail \\
\hline 4 & Beryl Gaffney Park & Municipal park \\
\hline 5 & Dominion Arboretum & Municipal park \\
\hline 6 & Heritage Park & Municipal park \\
\hline 7 & Greenbelt Pathway West & Recreational trail \\
\hline 8 & Pine Grove (Conroy Pit) & Municipal park \\
\hline 9 & $\begin{array}{l}\text { South March Highlands } \\
\text { Conservation Forest }\end{array}$ & Conservation area and fores \\
\hline 10 & Morris Island Conservation Area & Conservation area and forest \\
\hline 11 & Stoney Swamp & Conservation area and forest \\
\hline 12 & Petrie Island Park & Conservation area and forest \\
\hline 14 & Meadowbrook Park & Municipal park \\
\hline 15 & $\begin{array}{l}\text { Prescott \& Russell Recreational } \\
\text { Trail }\end{array}$ & Recreational trail \\
\hline 16 & Pinhey's Point Park & Conservation area and forest \\
\hline 17 & Brown's Inlet Park & Municipal park \\
\hline 18 & Fairmont Park & Municipal park \\
\hline 19 & $\begin{array}{l}\text { Carling Campus Northern Access } \\
\text { Trail }\end{array}$ & Recreational trail \\
\hline 20 & Shirley's Bay & Recreational trail \\
\hline 21 & Beacon Hill & Recreational trail \\
\hline 22 & Hog's Back Park & Municipal park \\
\hline 23 & Carp Hill & Conservation area and fores \\
\hline 24 & Greely & Municipal park \\
\hline
\end{tabular}

a 1 metre $^{2}$ white flannel cloth across the forest floor and surrounding vegetation for a total of at least three person-hours at each site, if the size of the area permitted, with less than three person-hours in smaller sites. The drag cloth was checked for ticks every 50 metres and geographic coordinates were recorded using a handheld global positioning system (GPS) device (Garmin eTrex 20x). Adults, nymphs and larvae were maintained alive in plastic vials and transported on ice to the laboratory at the University of Ottawa for species identification and possible testing.

\section{Laboratory testing}

All adults, nymphs and larvae were identified by microscopic examination for species verification and sex using standard taxonomic keys (18-20). Adult and nymphal I. scapularis ticks were tested for B. burgdorferi, A. phagocytophilum, and $B$. miyamotoi using quantitative polymerase chain reaction (qPCR) assays, which allow quantification of the amplified DNA molecules according to previously published protocols $(13,21)$. Prior to testing, the qPCR assays established at the University of Ottawa were validated using a panel of test samples provided by the National Microbiology Laboratory (NML) in Winnipeg. 
Ticks were dissected and total genomic DNA was extracted using the QIAamp DNA mini kit (QIAGEN Inc., Mississauga, Ontario). A duplex qPCR assay targeting the $23 \mathrm{~S}$ rRNA and the msp2 gene was used to identify $B$. burgdorferi sensu lato and A. phagocytophilum, respectively. Borrelia burgdorferi sensu stricto and $B$. miyamotoi DNA was then confirmed in positive samples by targeting their ospA and $g / p O$ genes, respectively. Amplification was carried out using the BioRad CFX96 Real-Time PCR Detection System. After amplification and real-time data acquisition, analysis was performed using the CFX Maestro software (BioRad, Hercules, California, US). Subsequent testing by nested PCR and sequencing was performed at NML for samples positive with screening primers but negative with confirmatory assays.

\section{Descriptive analyses}

Total tick density was calculated for each site as the total number of adult, nymph and larval I. scapularis ticks divided by the total person-hours of sampling, combining data from spring/summer and fall collections. Nymphal density was similarly calculated as the total number of $I$. scapularis nymphs in a given site divided by the total number of person-hours of sampling. Infection rates were calculated as the total number of ticks positive for B. burgdorferi, B. miyamotoi or A. phagocytophilum divided by the total number of ticks tested. Larvae were not tested because transovarial transmission of $B$. burgdorferi does not occur (13). Differences in tick density by site type were explored using one-way analysis of variance in Stata 15.0 (StataCorp, College Station, Texas, US).

\section{Results}

\section{Field sampling}

In total, we collected 239 I. scapularis ticks, including 194 adults, 26 nymphs and 19 larvae, during 135 person-hours of drag sampling. Ixodes scapularis ticks were detected at 16 of the 23 (70\%) sites (Figure 1). Other tick species were found at three sites: Haemaphysalis $(n=6)$ at two sites and Ixodes marxi $(n=1)$ at one site.

Overall mean I. scapularis density was 2.6 (standard deviation [SD] 4.0) per person-hour in Ottawa sites. Mean tick density differed by type of site, with significantly higher tick density in the recreational trail, conservation area/forest and provincial park sites with a mean (SD) of 4.1 (4.5) compared to the municipal parks mean (SD) of $0.3(0.5)(p<0.01)$. Risk areas based on a $5-\mathrm{km}$ radius from sites with tick occurrence were widely distributed around Ottawa, with highest coverage in forested areas of the western region of Ottawa and along the Ottawa River (Figure 2).

Figure 1: Map of Ottawa illustrating tick density in sites surveyed for active tick surveillance, 2017

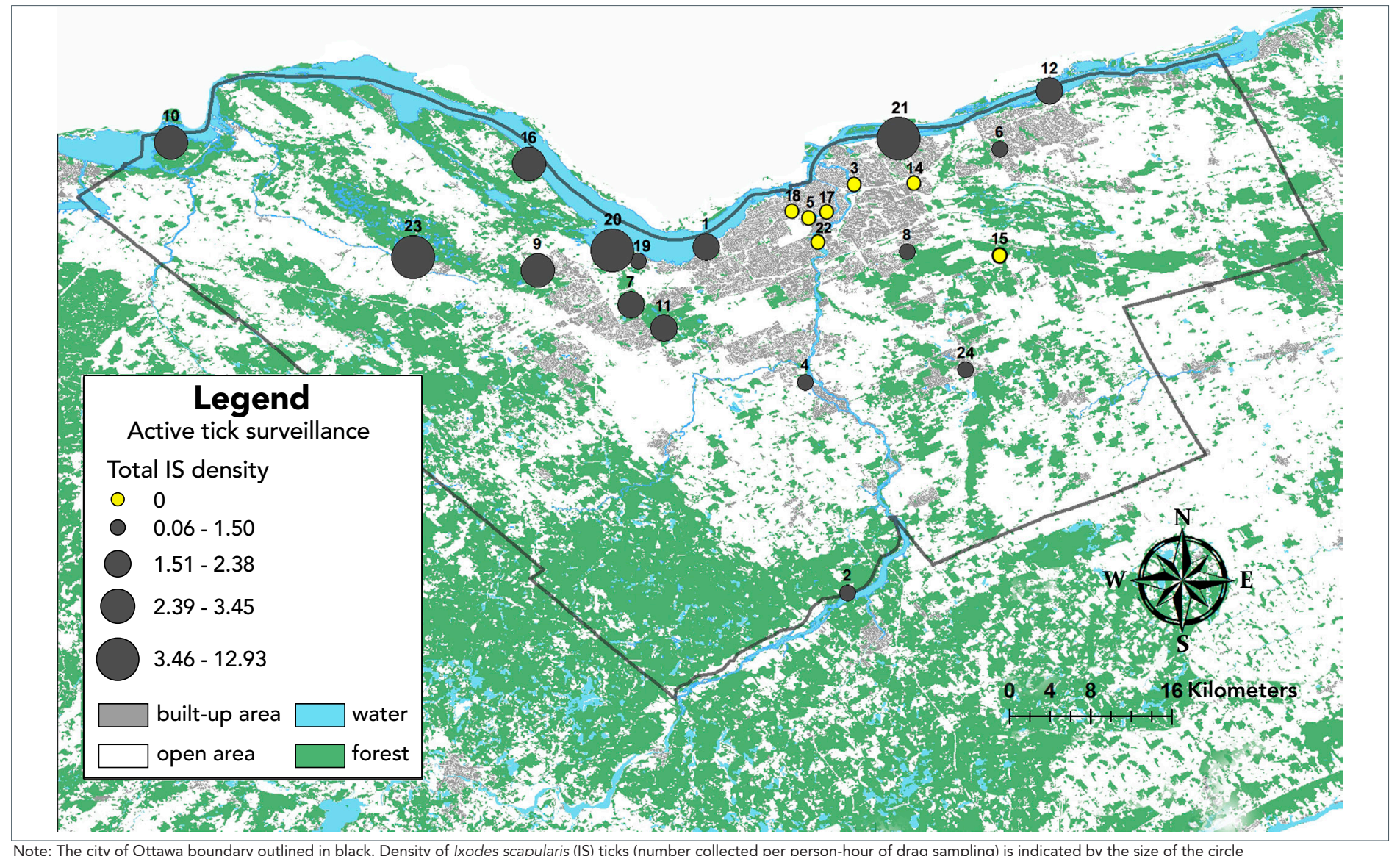


Figure 2: Map of Ottawa with estimated risk areas for ticks based on active surveillance, 2017

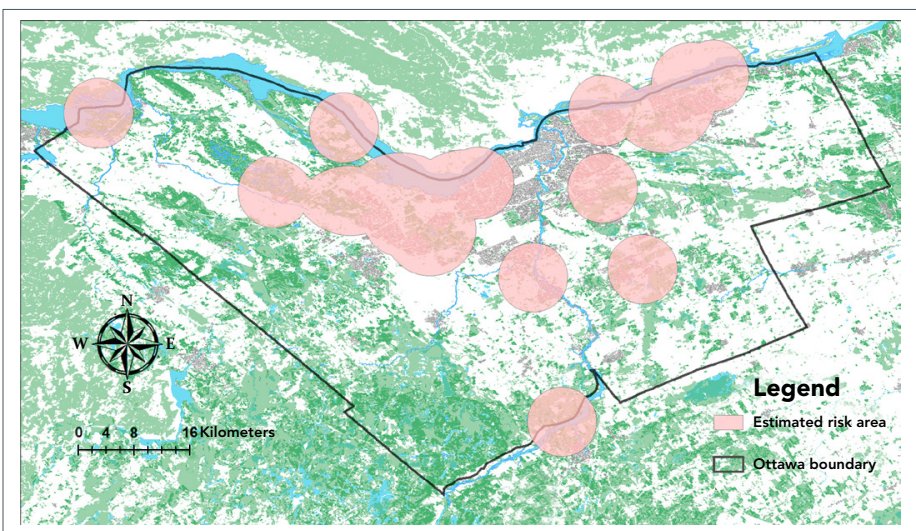

Note: Risk areas are defined using a 5-km radius from the centre of a location where blacklegged ticks were found by drag sampling and only reflect areas where drag sampling was conduct at 23 sites

\section{Laboratory analyses}

All 220 adult and nymphal I. scapularis ticks were tested for pathogens. Borrelia burgdorferi was detected in ticks from 11 of the 16 sites where I. scapularis were found. In total, 65 (29.5\%) of all tested ticks were positive for $B$. burgdorferi, and infection rates varied considerably by site, ranging from $0 \%$ to $50 \%$ (Table 2). Borrelia miyamotoi and A. phagocytophilum were detected in two sites in Ottawa representing $0.45 \%(n=1)$ and $0.91 \%(n=2)$ of the blacklegged ticks tested (Table 2).

\section{Discussion}

This study provides a recent picture of the distribution of I. scapularis ticks and their infection rates with $B$. burgdorferi and other pathogens of public health significance in urban, suburban and rural areas of the city of Ottawa, where the number of Lyme disease cases have been rapidly increasing. We show that $70 \%$ of sampled sites were positive for I. scapularis ticks, with highest tick density observed in recreational trails and conservation areas/forests, signalling the potential for human-tick encounter in these sites. Prevalence of infection with B. burgdorferi in collected ticks varied considerably, with an average of $29.5 \%$ in the 16 Ottawa sites where I. scapularis were found.

The study was limited by small numbers of collected ticks $(n<30)$ in the majority of sites within Ottawa, which reduces the robustness of the pathogen prevalence estimates. Therefore, infection rates should be interpreted with caution for these sites.

Table 2: Active surveillance of Ixodes scapularis ticks in Ottawa, ON, 2017

\begin{tabular}{|c|c|c|c|c|c|c|c|c|c|c|}
\hline \multirow[t]{2}{*}{$\begin{array}{l}\text { Site } \\
\text { ID }\end{array}$} & \multirow[t]{2}{*}{$\begin{array}{l}\text { Person-hours drag } \\
\text { sampling } \\
\text { (n) }\end{array}$} & \multicolumn{4}{|c|}{ Ixodes scapularis abundance } & \multicolumn{2}{|c|}{$\begin{array}{l}\text { Ixodes scapularis density } \\
\text { per person-hour } \\
\text { (n) }\end{array}$} & \multicolumn{3}{|c|}{ Infection rate (\%) } \\
\hline & & Adult & Nymph & Larva & Total & Nymph & Total & $B b$ & $B m$ & $A p$ \\
\hline 1 & 8.4 & 15 & 0 & 0 & 15 & 0 & 1.8 & $13.3^{c}$ & $0^{b}$ & 0 \\
\hline 2 & 6.9 & 0 & 1 & 0 & 1 & 0.3 & 0.2 & 0 & 0 & 0 \\
\hline 3 & 6.0 & 0 & 0 & 0 & 0 & 0 & 0 & NA & NA & NA \\
\hline 4 & 11.2 & 1 & 0 & 0 & 1 & 0 & 0.1 & 0 & 0 & 0 \\
\hline 5 & 7.0 & 0 & 0 & 0 & 0 & 0 & 0 & NA & NA & NA \\
\hline 6 & 7.7 & 1 & 0 & 0 & 1 & 0 & 0.1 & 0 & 0 & 0 \\
\hline 7 & 8.0 & 10 & 6 & 1 & 17 & 1.6 & 2.4 & $43.8^{d}$ & 0 & 0 \\
\hline 8 & 8.3 & 0 & 2 & 3 & 5 & 0.5 & 0.6 & 0 & 0 & 0 \\
\hline 9 & 7.2 & 23 & 2 & 0 & 25 & 0.6 & 3.5 & $32.0^{d}$ & 0 & 0 \\
\hline 10 & 8.5 & 25 & 4 & 0 & 29 & 1.0 & 3.4 & $34.5^{d}$ & 0 & $3.5^{c}$ \\
\hline 11 & 13.2 & 11 & 11 & 4 & 26 & 1.6 & 2.0 & $31.8^{d}$ & 0 & 0 \\
\hline 12 & 5.3 & 12 & 0 & 0 & 12 & 0 & 2.3 & $8.33^{c}$ & 0 & 0 \\
\hline 14 & 3.8 & 0 & 0 & 0 & 0 & 0 & 0 & NA & NA & NA \\
\hline 15 & 6.3 & 0 & 0 & 0 & 0 & 0 & 0 & NA & NA & NA \\
\hline 16 & 5.7 & 8 & 0 & 11 & 19 & 0 & 3.4 & $50.0^{d}$ & 0 & 0 \\
\hline 17 & 4.3 & 0 & 0 & 0 & 0 & 0 & 0 & NA & NA & NA \\
\hline 18 & 4.4 & 0 & 0 & 0 & 0 & 0 & 0 & NA & NA & NA \\
\hline 19 & 4.0 & 6 & 0 & 0 & 6 & 0 & 1.5 & $50.0^{d}$ & 0 & 0 \\
\hline 20 & 4.0 & 46 & 0 & 0 & 46 & 0 & 11.5 & $43.5^{d}$ & $2.2^{\mathrm{c}}$ & $2.2^{c}$ \\
\hline 21 & 1.2 & 15 & 0 & 0 & 15 & 0 & 12.9 & $13.3^{c}$ & 0 & 0 \\
\hline 22 & 1.0 & 0 & 0 & 0 & 0 & 0 & 0 & NA & NA & NA \\
\hline 23 & 1.5 & 18 & 0 & 0 & 18 & 0 & 12.0 & $5.56^{\mathrm{c}}$ & 0 & 0 \\
\hline 24 & 2.0 & 3 & 0 & 0 & 3 & 0 & 1.50 & 0 & 0 & 0 \\
\hline
\end{tabular}

Abbreviations: Ap, Anaplasma phagocytophilum; Bb, Borrelia burgdorferi; Bm, Borrelia miyamoto; NA, not applicable; n, number; ON, Ontario

Note: Site 13 was deleted as it was outside the city limits

a Only adult and nymphal blacklegged ticks were tested

b Zeros (green) no infected ticks

'Infection rate $2-15 \%$ (yellow)

${ }^{d}$ Infection rate $>20 \%$ (red) 
Sampling was restricted from June to October due to heavy spring rainfall, which may have limited our ability to detect ticks in some sites. Detection may also have been limited by the use of drag sampling, which has been reported to be $50 \%$ sensitive (15), so some sites may have been considered falsely negative for blacklegged ticks because the density of established tick populations was very low.

Given the widespread distribution of I. scapularis ticks around the city of Ottawa and the potential for further expansion of tick populations, this study provides an important baseline for monitoring ticks and tick-borne pathogens of public health significance in this region. Although the bacterium causing Lyme disease was the most common type of tick infection, infections causing anaplasmosis and tick-borne relapsing fever were also found, suggesting the potential risk of emergence of these new pathogens in Ottawa.

Further research is needed to better understand the associations between expanding environmental risk in the area and human Lyme disease exposure. Ongoing active tick surveillance is needed over consecutive years. To determine whether tick populations are established, all three life stages of the tick need to be detected for two consecutive years. This information can be used to inform public health actions such as continued public health messaging to health care providers and the public to raise awareness of Lyme disease and other emerging tick-borne infections, associated risks, diagnostic tests as well as both curative and preventive measures.

\section{Authors' statement}

MAK - Conception, analysis and data interpretation, writing and editing of this article

RK, AS, CT, BT - Fieldwork and laboratory analysis, analysis and data interpretation, critical revision of this article

$A D, L R L$ - Laboratory analysis, data interpretation, critical revision of the article

\section{Conflict of interest}

None.

\section{Acknowledgements}

We would like to thank Ottawa Public Health for providing data on human Lyme disease cases. We also thank Itai Malkin and Merlin Caron-Levesque for their contributions to the fieldwork.

\section{Funding}

This study was funded by a grant from the Canadian Institutes for Health Research (CIHR) to Manisha A Kulkarni for a research project entitled Public Health Risk Assessment Tools for Emerging Vector-borne Diseases, and was further supported by the Public Health Agency of Canada.

\section{References}

1. Steere AC, Coburn J, Glickstein L. The emergence of Lyme disease. J Clin Invest 2004 Apr;113(8):1093-101. https://doi. org/10.1172/JCl21681. PubMed (https://www.ncbi.nlm.nih. gov/pubmed/15085185?dopt=Abstract).

2. Thompson C, Spielman A, Krause PJ. Coinfecting deer-associated zoonoses: lyme disease, babesiosis, and ehrlichiosis. Clin Infect Dis 2001 Sep;33(5):676-85. https:// doi.org/10.1086/322681. PubMed (https://www.ncbi.nlm. nih.gov/entrez/query.fcgi?cmd=Retrieve \&db=PubMed\&li st_uids=11486290\&dopt=Abstract).

3. Dennis DT, Nekomoto TS, Victor JC, Paul WS, Piesman J. Reported distribution of Ixodes scapularis and Ixodes pacificus (Acari: Ixodidae) in the United States. J Med Entomol 1998 Sep;35(5):629-38. https://doi.org/10.1093/ jmedent/35.5.629. PubMed (https://www.ncbi.nlm.nih. gov/entrez/query.fcgi?cmd=Retrieve \&db=PubMed\&lis t_uids=9775584\&dopt=Abstract)

4. Ogden NH, Bigras-Poulin M, O'Callaghan CJ, Barker IK, Lindsay LR, Maarouf A Smoyer-Tomic KE, Waltner-Toews $D$, Charron D. A dynamic population model to investigate effects of climate on geographic range and seasonality of the tick Ixodes scapularis. Int J Parasitol 2005 Apr;35(4):375-89. https://doi.org/10.1016/j.ijpara.2004.12.013. PubMed (https://www.ncbi.nlm.nih.gov/entrez/query.fcgi?cmd=Retrie ve\&db=PubMed\&list_uids=15777914\&dopt=Abstract)

5. Lindquist EE, Galloway TD, Artsob H, Lindsay LR, Drebot M, Wood H. Robbins RG. A handbook to the ticks of Canada (Ixodida: Ixodidae, Argasidae). Ottawa: Biological Survey of Canada; 2016. https://doi.org/10.3752/9780968932186

6. Ogden NH, Maarouf A, Barker IK, Bigras-Poulin M, Lindsay LR, Morshed MG O'Callaghan CJ, Ramay F, Waltner-Toews D. Charron DF. Climate change and the potential for range expansion of the Lyme disease vector Ixodes scapularis in Canada. Int J Parasitol 2006 Jan;36(1):63-70. https://doi. org/10.1016/j.ijpara.2005.08.016. PubMed (https://www. ncbi.nlm.nih.gov/entrez/query.fcgi?cmd=Retrieve\&db=PubM ed\&list_uids=16229849\&dopt=Abstract). 
7. Clow KM, Leighton PA, Ogden NH, Lindsay LR, Michel P, Pearl DL, Jardine CM. Northward range expansion of Ixodes scapularis evident over a short timescale in Ontario, Canada. PLoS One 2017 Dec;12(12):e0189393. https://doi. org/10.1371/journal.pone.0189393 . PubMed (https://www. ncbi.nlm.nih.gov/entrez/query.fcgi?cmd=Retrieve\&db=PubM ed\&list_uids=29281675\&dopt=Abstract)

8. Clow KM, Ogden NH, Lindsay LR, Michel P, Pearl DL, Jardine CM. Distribution of ticks and the risk of lyme disease and other tick-borne pathogens of public health significance in Ontario, Canada. Vector Borne Zoonotic Dis 2016 Apr;16(4):215-22. https://doi.org/10.1089/ vbz.2015.1890. PubMed (https://www.ncbi.nlm.nih. gov/entrez/query.fcgi?cmd=Retrieve \&db=PubMed\&lis t_uids=26870937\&dopt=Abstract)

9. Leighton PA, Koffi JK, Pelcat Y, Lindsay LR, Ogden NH. Predicting the speed of tick invasion: an empirical model of range expansion for the Lyme disease vector Ixodes scapularis in Canada. J Appl Ecol 2012;49(2):457-64. https:// doi.org/10.1111/j.1365-2664.2012.02112.x

10. Soucy JR, Slatculescu AM, Nyiraneza C, Ogden NH, Leighton PA, Kerr JT, Kulkarni MA. High-resolution ecological niche modeling of Ixodes scapularis ticks based on passive surveillance data at the northern frontier of Lyme Disease emergence in North America. Vector Borne Zoonotic Dis 2018 May;18(5):235-42. https://doi.org/10.1089/ vbz.2017.2234. PubMed (https://www.ncbi.nlm.nih. gov/entrez/query.fcgi?cmd=Retrieve \&db=PubMed\&lis t_uids=29565748\&dopt=Abstract)

11. Ottawa Public Health. Reportable diseases by year. Reportable Diseases by Year for Ottawa Residents (Number of Cases). Ottawa: Ottawa Public Health. http://www. ottawapublichealth.ca/en/reports-research-and-statistics/ infectious-diseases.aspx\#cases

12. Edginton S, Guan TH, Evans G, Srivastava S. Human granulocytic anaplasmosis acquired from a blacklegged tick in Ontario. CMAJ 2018 Mar;190(12):E363-6. https://doi. org/10.1503/cmaj.171243. PubMed (https://www.ncbi.nlm. nih.gov/entrez/query.fcgi?cmd=Retrieve \&db=PubMed\&li st_uids $=29581163 \&$ dopt $=$ Abstract)

13. Dibernardo A, Cote T, Ogden NH, Lindsay LR. The prevalence of Borrelia miyamotoi infection, and co-infections with other Borrelia spp. in Ixodes scapularis ticks collected in Canada. Parasit Vectors 2014 Apr;7:183. https://doi. org/10.1186/1756-3305-7-183. PubMed (https://www.ncbi. nlm.nih.gov/entrez/query.fcgi?cmd=Retrieve\&db=PubMed\&l ist_uids=24731287\&dopt=Abstract).

14. Krause PJ, Schwab J, Narasimhan S, Brancato J, Xu G, Rich SM. Hard tick relapsing fever caused by
Borrelia miyamotoi in a child. Pediatr Infect Dis J 2016 Dec;35(12):1352-4. https://doi.org/10.1097/ INF.0000000000001330. PubMed (https://www.ncbi.nlm. nih.gov/entrez/query.fcgi?cmd=Retrieve \&db=PubMed\&li st_uids=27626914\&dopt=Abstract)

15. Ogden NH, Koffi JK, Lindsay LR. Assessment of a screening test to identify Lyme disease risk. Can Commun Dis Rep 2014 Mar;40(5):83-7. https://www.canada.ca/ en/public-health/services/reports-publications/canadacommunicable-disease-report-ccdr/monthly-issue/2014-40/ ccdr-volume-40-5-march-6-2014/ccdr-volume-40-5march-6-2014-1.html. PubMed (https://www.ncbi.nlm.nih. gov/entrez/query.fcgi?cmd=Retrieve \&db=PubMed\&lis t_uids=29769886\&dopt=Abstract)

16. Statistics Canada. Focus on geography series, 2016 Census. Statistics Canada Catalogue no. 98-404-X2016001. Ottawa: Data products, 2016 Census; 2017. https://www12.statcan. gc.ca/census-recensement/2016/as-sa/fogs-spg/Facts-caneng.cfm? Lang $=$ Eng \&GK $=\mathrm{CAN} \& \mathrm{GC}=01 \& \mathrm{TOPIC}=1$

17. Public Health Ontario. Active tick dragging: Standard operating procedure. Toronto: Queen's Printer for Ontario; 2015. https://www.publichealthontario.ca/en/eRepository/ Active_tick_dragging_SOP.pdf

18. Keirans JE, Litwak TR. Pictorial key to the adults of hard ticks, family Ixodidae (Ixodida: Ixodoidea), east of the Mississippi River. J Med Entomol 1989 Sep;26(5):435-48. https://doi. org/10.1093/jmedent/26.5.435. PubMed (https://www.ncbi. $\mathrm{nlm}$.nih.gov/entrez/query.fcgi?cmd=Retrieve\&db=PubMed\&l ist_uids $=2795615 \&$ dopt $=$ Abstract $)$

19. Keirans JE, Hutcheson HJ, Durden LA, Klompen JS. Ixodes (Ixodes) scapularis (Acari:Ixodidae): redescription of all active stages, distribution, hosts, geographical variation, and medical and veterinary importance. J Med Entomol 1996 May;33(3):297-318. https://doi.org/10.1093/ jmedent/33.3.297. PubMed (https://www.ncbi.nlm.nih. gov/entrez/query.fcgi?cmd=Retrieve $\& d b=P u b M e d \& l i s$ t_uids=8667375\&dopt=Abstract).

20. Clifford C. The larval ixodid ticks of the Eastern United States (Acarina-lxodidae). College Park (MD): University of Maryland; 1961.

21. Courtney JW, Kostelnik LM, Zeidner NS, Massung RF. Multiplex real-time PCR for detection of anaplasma phagocytophilum and Borrelia burgdorferi. J Clin Microbiol 2004 Jul;42(7):3164-8. https://doi.org/10.1128/ JCM.42.7.3164-3168.2004. PubMed (https://www.ncbi.nlm. nih.gov/entrez/query.fcgi?cmd=Retrieve $\& d b=$ PubMed \&li st_uids=15243077\&dopt=Abstract) 